\title{
Formation of an optimal cement matrix for vibropress products
}

\author{
Igor Romanenko*, Alexey Fadin, Irina Petrovnina, and Maria Romanenko \\ Penza State University of Architecture and Construction, 28 German Titov, Penza, 440028, Russia
}

\begin{abstract}
Modern approaches to the formation of new generation concretes make it possible to replace part of the fine aggregate with finely ground mineral powders, which are by-products of metallurgical and chemical industries, the construction industry, as well as various substandard quartz sands. In the studies carried out, metallurgical slags (MS), broken glass (BG), dust from gas cleaning of metallurgical production (DGCMP), and ground quartz sand (GQS) were used. The aim of the study is to obtain an optimal flow rate of a hydraulic binder by forming an optimal cement matrix. The dosage of finely ground powders varied in the range of $20-49 \%$ of the portland cement consumption. It has been established that the most acceptable finely ground mineral powders in compositions for the production of vibropress products are: quartz ground sand, metallurgical granulated slag of blast furnace production, gas cleaning dust and ground glass. Powders obtained on the basis of glass scrap can be considered as an additional raw material base in the production of materials for road-building purposes. Operational properties such as water absorption and the rate of concrete curing indicate their prospects. However, the economic costs of collecting, sorting glass, obtaining a powder with a specific surface area of $3000 \mathrm{~cm}^{2} / \mathrm{g}$ are not reasonable at this point in time.
\end{abstract}

\section{Introduction}

Modern production of concrete based on Portland cement is not complete without the widespread use of fine powders, including fine powders. This trend has been seen since the late $60 \mathrm{~s}$ of the twentieth century. These powders were considered as fillers with an optimal consumption of $5-20 \%$ of the mass of Portland cement $[1,2,3,4]$. The raw materials were: ash from coal combustion, granulated slag, dehydrated clay, crushed expanded clay and micro silica. They contain aluminosilicates and silicon-containing materials in their composition. The considered powders contribute to the formation of an additional pozzolanic reaction (cementing ability) during hardening of the binder, as well as to obtain optimal packing of the composite material with an increase in its density $[2,5,6]$. At the same time, it has not been established with high reliability how to control the properties of composite materials in a targeted manner by changing the filling of the cement matrix and reducing the proportion of Portland cement in the system [1, 7]. In open sources, it was

\footnotetext{
* Corresponding author: rom1959@yandex.ru
} 
practically not analyzed how the fineness of grinding of powders and the ratio of various oxides affect the kinetics of the strength gain of concrete and the ability to form internal defects in the form of cracks. The conducted research is aimed at obtaining highly efficient vibropress concretes with a minimum consumption of Portland cement and a maximum filling of the system with finely ground powders to ensure a good and smooth surface, as well as sufficient physical and mechanical characteristics. Fillers with pozzolanic reactivity will significantly change the physical and mechanical properties of concrete. Vibrocompressed concrete with fillers based on mineral powders will provide both economic and environmental effects for the region and business.

\section{Materials and research methods}

\subsection{Materials}

The following materials were used for the study: Portland cement PTC M500 D0 (CEM I $42.5 \mathrm{H})$ - "Asia Cement" - the city of Nikolsk; sand of the Chaadaevsky quarry with a fineness module of $\mathrm{Mcr}=1,4-1,6$; crushed quartz sand of the Aleksandrovsky quarry (GQS) with a specific surface area $\mathrm{Ssp}=4500 \mathrm{~cm}^{2} / \mathrm{g}$; ground glass breakage of container glass (BG), powder specific surface $S s p=2600-3000 \mathrm{~cm}^{2} / g$; ground granulated slag of the Novolipetsk Metallurgical Plant (MS) with a specific surface area Ssp $=3000 \mathrm{~cm}^{2} / \mathrm{g}$, true density $2530 \mathrm{~kg} / \mathrm{m}^{3}$; gas cleaning dust of the Tula Metallurgical Combine (DGCMP) with $\mathrm{Ssp}=4100 \mathrm{~cm}^{2} / \mathrm{g}$; granite crushed stone, fraction 2-4 $\mathrm{mm}$ and 5-10 $\mathrm{mm}$ (Karelian granite); hyperplasticizer - Hedital GP-9 $\gamma$ (dry residue (DR) $-19 \mathrm{~g} / 100 \mathrm{ml}$ ); drinking water.

\subsection{Research methodology}

The methodological feature of the research is the production of high-strength vibropress products with a minimum consumption of Portland cement. The experimental technique is described in detail in the article [5]. The physical and mechanical properties of concretes were determined by cubes with a size of $100 \times 100 \times 100 \mathrm{~mm}$, tested for compression at the age of 7, 28, 90 and 360 days of hardening under normal conditions at a humidity of $90 \%$ and a temperature of $\mathrm{T}=20 \pm 5{ }^{\circ} \mathrm{C}$. Cubes were molded on a vibropress with a weight of $120 \mathrm{~kg}$ for 2 samples, molded simultaneously on a laboratory vibrating platform. Water absorption was determined by immersing concrete samples in water at the age of 28 days of hardening under normal conditions and holding for 24 hours according to the generally accepted technique $[8,9]$. Ground powders were obtained using a three-stage preparation technology. At the first stage, the materials were dried to constant weight in an oven at a temperature of $\mathrm{T}=105{ }^{\circ} \mathrm{C}$, and cooled in a desiccator to ambient temperature. The second stage is crushing in a jaw crusher to a fraction of $0-5 \mathrm{~mm}$. At the third stage, the resulting material was ground in a ball mill to a specific surface area set in the experiment, which was controlled by a PSKh-10AK device.

\section{Discussion, results}

The table 1 shows the results of the optimized compositions of vibropress concretes and their experimental compression tests. 
Table 1. Physical and mechanical properties of vibropress concrete for the production of paving slabs

\begin{tabular}{|c|c|c|c|c|c|c|c|c|c|c|}
\hline \multirow{3}{*}{ Ingredients } & \multicolumn{10}{|c|}{ Consumption per $1 \mathrm{~m}^{3}, \mathrm{~kg}$} \\
\hline & \multicolumn{10}{|c|}{ Squad number } \\
\hline & 1 & 2 & 3 & 4 & 5 & 6 & 7 & 8 & 9 & 10 \\
\hline CEM I $42.5 \mathrm{H}$ & 277 & 362 & 235 & 328 & 240 & 270 & 280 & 219 & 215 & 458 \\
\hline Natural sand & - & - & - & - & - & - & - & - & - & 1100 \\
\hline Broken glass (BG) & 181 & 96 & - & - & - & - & 70 & - & - & - \\
\hline $\begin{array}{l}\text { Ground quartz sand } \\
\text { (GQS) }\end{array}$ & - & - & - & - & - & - & - & 201 & 198 & - \\
\hline $\begin{array}{l}\text { Metallur-gical slags } \\
\text { (MS) }\end{array}$ & - & - & 223 & 130 & - & - & 70 & - & - & - \\
\hline $\begin{array}{l}\text { Dust from gas cleaning } \\
\text { of metallur-gical } \\
\text { production (DGCMP) }\end{array}$ & - & - & - & - & 218 & 188 & - & - & - & - \\
\hline Sand fr. $0,16 \mathrm{~mm}$ & 554 & 543 & 625 & 615 & 576 & 528 & - & 500 & 610 & - \\
\hline Sand fr. $0,63-2,5 \mathrm{~mm}$ & 898 & 957 & 800 & 816 & 870 & 928 & 750 & 684 & 638 & - \\
\hline Crushed stone $2,5-5 \mathrm{~mm}$ & 454 & 261 & 350 & 408 & 348 & 353 & 1140 & 649 & 546 & 750 \\
\hline Hedital GP-9 $\gamma-0,75 \%$ & 7,0 & 10 & 7,5 & 7,7 & 6,5 & 6,0 & 7,0 & 7,3 & 7,25 & 10,0 \\
\hline Water & 73 & 78 & 90 & 92 & 78,3 & 86 & 90 & 89 & 90 & 130 \\
\hline Water-cement ratio & 0,26 & 0,22 & 0,38 & 0,28 & 0,33 & 0,32 & 0,32 & 0,41 & 0,42 & 0,28 \\
\hline Forming density, $\mathrm{kg} / \mathrm{m}^{3}$ & 2437 & 2297 & 2323 & 2389 & 2330 & 2353 & 2400 & 2342 & 2297 & 2438 \\
\hline Density for 7 days, $\mathrm{kg} / \mathrm{m}^{3}$ & 2322 & 2196 & 2240 & 2276 & 2250 & 2241 & 2349 & 2219 & 2222 & 2331 \\
\hline Density for 7 days, $\mathrm{MPa}$ & 16,63 & 22,11 & 23,24 & 19,54 & 24,16 & 24,13 & 42,8 & 34,58 & 29,63 & 35,18 \\
\hline $\begin{array}{l}\text { Density for } 28 \text { days, } \\
\mathrm{kg} / \mathrm{m}^{3}\end{array}$ & 2258 & 2074 & 2140 & 2157 & 2135 & 2116 & 2245 & 2226 & 2219 & 2211 \\
\hline Density for 28 days, $\mathrm{MPa}$ & 17,56 & 22,12 & 26,25 & 20,00 & 27,66 & 26,62 & 47,09 & 49,67 & 44,89 & 41,18 \\
\hline $\begin{array}{l}\text { Density for } 90 \text { days, } \\
\mathrm{kg} / \mathrm{m}^{3}\end{array}$ & 2114 & 2045 & 2070 & 2078 & 2046 & 2075 & 2200 & 2211 & 2210 & 2210 \\
\hline Density for 90 days, $\mathrm{MPa}$ & 38,67 & 33,12 & 46,29 & 43,80 & 34,67 & 32,19 & 51,66 & 55,39 & 46,76 & 43,38 \\
\hline $\begin{array}{l}\text { Density for } 360 \text { days, } \\
\mathrm{kg} / \mathrm{m}^{3}\end{array}$ & 2135 & 2079 & 2108 & 2112 & 2123 & 2130 & 2265 & 2217 & 2205 & 2215 \\
\hline $\begin{array}{l}\text { Density for } 360 \text { days, } \\
\text { MPa }\end{array}$ & 40,00 & 35,83 & 49,95 & 45,03 & 36,41 & 34,86 & 53,07 & 56,51 & 48,30 & 45,55 \\
\hline $\begin{array}{l}\text { Vodopo- } \\
\text { ironing at the age of } 28 \\
\text { days, } \%\end{array}$ & 3,2 & 3,6 & 4,56 & 4,80 & 4,79 & 4,9 & 3,8 & 3,34 & 3,54 & 5,9 \\
\hline $\begin{array}{l}\text { Type of filling } \\
\text { body matrix }\end{array}$ & $\mathrm{B}$ & & $\mathrm{M}$ & IS & DG & CMP & $\mathrm{BG}+\mathrm{MS}$ & $\mathrm{GC}$ & & $\begin{array}{l}\text { Con- } \\
\text { trol }\end{array}$ \\
\hline
\end{tabular}

From the results obtained on the optimization of the compositions of the consumption of materials per $1 \mathrm{~m}^{3}$, it can be seen that approximately in all compositions the optimum 
moisture content of the mixture was achieved, which is confirmed by good molding and approximately the same density of the samples.

To achieve the maximum density of concrete samples and to be able to remove the formwork after molding, the water-cement ratio ratio varies from 0,22 to 0,42 , which indicates the various properties of fillers - finely ground powders. At the same time, the molding density of the concrete mixture varied in the range of $2297-2438 \mathrm{~kg} / \mathrm{m}^{3}$. Samples of concrete cubes are formed with a perfectly flat surface, sharp edges and no smudges. After 7 days of hardening, the strength characteristics of concretes with finely ground structure modifiers significantly differed from those of the control composition molded on standard sand and gravel. Positioning in a comparison row from the smallest to the largest of the results obtained allows us to obtain the following dependence: $\mathrm{BG}<\mathrm{MS}<\mathrm{DGCMP}$ $<$ GQS $<$ Control $<$ (BG + MS). The excess of strength of samples with a complex filler of ground granulated slag and ground breaking of container glass relative to the control composition is $122 \%$, and relative to samples with filling with ground breaking of container glass $-214 \%$. Moreover, the consumption of Portland cement in the composition of № 7 is reduced by 39 \% (compared with the control № 10).

At the age of 90 days, the dependence of the strength of the samples on the type of filler changes: DGCMP $<$ BG $<$ Control $<\mathrm{MS}<\mathrm{GQS}<(\mathrm{BG}+\mathrm{MS})$. Vibroconcrete compositions № 3, 4; 8, 9 and 7 exceed the strength of the control samples by 2-22\%. Samples of compositions № 1, 2 and 5, 6 have lower compressive strength values by 18-24 $\%$ (compared to control № 10).

At the age of 360 days, a series of dependences of the compressive strength on the type of filler is as follows: DGCMP $<\mathrm{BG}<$ Control $<\mathrm{MS}<\mathrm{GQS}<(\mathrm{BG}+\mathrm{MS})$, that is, the dependence that was achieved at the age of 90 days is confirmed.

Interesting data were recorded on the water absorption of samples at the age of 28 days in a normal hardening chamber. The comparative series is presented in the following sequence: $(\mathrm{BG}=\mathrm{GQS})<\mathrm{BG}+\mathrm{MS}<\mathrm{MS}<\mathrm{DGCMP}<$ Control. Samples of concrete filled with ground glass have the lowest water absorption value of the entire series. Thus, the use of this type of filler is promising, which will allow for further research to select the optimal filling of the system.

\section{Conclusions}

1. A positive effect of the dosage of five types of ground fillers of a cement matrix on the properties of vibropress concretes has been revealed. The explication period of the experiment is 360 days. Micro fillers were used as a complex in an amount of $21-49 \%$ to replace Portland cement by weight. The control mixture without finely ground filler powders was compared in terms of compressive strength with five mixtures containing ground granulated slag, ground glass breakage of container glass, ground quartz sand, and gas cleaning dust.

2. The importance of long term testing has been proven. Significant changes in compressive strength occurred in the period from 28 days to 90 days, and later these patterns did not change until the end of the explication period $[10,11]$.

3. The most optimal modifier of the cement matrix is ground quartz sand with a specific surface area $\mathrm{Ssp}=4000-5000 \mathrm{~cm}^{2} / \mathrm{g}$.

4. The lowest rates of strength gain are possessed by vibropress concretes with the addition of ground broken container glass, however, the water absorption of these concretes is $3,4 \%$ on average, which is lower than all other investigated compositions.

5. The use of ground mineral powders can reduce the consumption of Portland cement by $22-49 \%$ relative to the control composition, which ensures a reduction in the cost of production, improves the environmental situation in the region due to the disposal of 
waste from various industries, reduces carbon dioxide emissions into the atmosphere by reducing the production of Portland cement at specialized enterprises.

6. The use of finely dispersed ground mineral powders together with hyperplasticizers in cement compositions and concretes opens up broad prospects for obtaining composite materials with high strength performance properties at a rational consumption of the binder.

\section{References}

1. R.T. Filho, J. Gonçalves, B. Americano, E. Fairbairn, Potential for use of crushed waste calcined-clay brick as a supplementary cementitious material in Brazil, Cem. Concr. Res., v. 37, pp. 1357-1365 (2007)

2. V.I. Kalashnikov, V.L. Khvastunov, A.A. Kartashov, M.N. Moroz, New geopolymer materials from rocks, activated by small additions of slag and alkalis, Current state and development prospects of building materials science: Eighth academic readings of the Department of Building Sciences of the RAASN, Samara, v. 8, pp. 205-209 (2004)

3. P.G. Komokhov, A.M. Kharitonov, Simulation-numerical model of the structure and properties of cement stone, Proceedings of universities. Building, v. 4(592), pp. 10-16 (2008)

4. Nekhoroshev A.V., Development of physicochemical concepts of hardening of mineral binders, Application of efficient materials and structures in rural construction, (M., 1984)

5. I. Romanenko, A. Fadin, I. Petrovnina, M. Romanenko, Influence of fine quartz sand faction on the properties of composite material, Materials Today: Proceedings (2020)

6. S.U. Khan, M.F. Nuruddin, T. Ayub, N. Shafiq, Effects of Different Mineral Admixtures on the Properties of Fresh Concrete, Sci. World J v. 2014, 11 (2014)

7. Y. Jiang, T. Ling, K.H. Mo, C. Shi, A critical review of waste glass powder-Multiple roles of utilization in cement-based materials and construction products, J. Environ. Manag, v. 242 pp. 440-449 (2019)

8. L. Turanli, F. Bektas, P. Monteiro, Use of ground clay brick as a pozzolanic material to reduce the alkaliesilica reaction, Cem. Concr. Res., v. 33, pp. 1539-1542 (2003)

9. V.W. Tam, X. Gao, C.M. Tam, Microstructural analysis of recycled aggregate concrete produced from two-stage mixing approach, Cem. Concr. Res, v. 35, pp. 1195-1203 (2005)

10. A.F. Omran, D.E. Morin., D. Harbec, A. Tagnit-Hamou, Long-term performance of glass-powder concrete in large-scale field applications, Constr. Build. Mater, v. 33, pp. 43-58 (2017)

11. Ortega J.M., Letelier V., Solas C., Miró M., Moriconi G., Climent M.Á., Sánchez I. Influence of Waste Glass Powder Addition on the Pore Structure and Service Properties of Cement Mortars (Sustainability, 2018) 